\title{
POTENSI DAN KENDALA PENGEMBANGAN PARIWISATA BERBASIS \\ KEKAYAAN ALAM DENGAN PENDEKATAN MARKETING PLACES (STUDI KASUS PENGEMBANGAN PARIWISATA DI KABUPATEN BOJONEGORO)
}

\author{
Soedarso, Muchammad Nurif, Windiani
}

\begin{abstract}
Abstrak
Sebagai negara yang sedang berkembang, Indonesia saat ini tengah aktif mengembangkan diri dalam segala bidang. Pengembangan kegiatankegiatan di setiap sektor tentunya membutuhkan dana yang tidak sedikit. Penelitian ini memfokuskan diri pada bagaimana mengembangkan sebuah potensi wisata suatu daerah. Metode yang digunakan adalah marketing places. Pada makalah ini akan dipaparkan hasil utama penelitian terutama dari sisi potensi dan kendala. Secara garis besar setiap daerah harus mengembangkan sektor pariwisata dengan memanfaatkan sumber daya seoptimal mungkin. Salah satu sektor yang masih belum dioptimalkan pengembangannya adalah sektor pariwisata, meskipun dalam penyusunan kebijakannya, strategi untuk sektor ini telah sering dirumuskan, namun ternyata pelaksanaannya masih mengalami kendala seperti yang juga dialami oleh Pemerintah Kabupaten Bojonegoro.
\end{abstract}

Kata kunci: Pengembangan, Potensi, Kendala, Pariwisata, Bojonegoro

Dalam beberapa tahun (sebelum krisis moneter) volume arus wisatawan yang berkunjung ke Indonesia meningkat, namun dengan adanya musibah nasional berupa krisis moneter, arus wisatawan sejak tahun 1998 cenderung menurun, akan tetapi sejak suksesnya pemilihan umum dan sidang umum MPR, keadaan berangsur-angsur membaik, meskipun belum bisa dikatakan stabil. Akan tetapi hal tersebut juga menimbulkan masalah, yakni bahwa arus wisatawan tidak merata dan hanya terpusat pada beberapa Daerah Tujuan Wisata (DTW) utama, terutama Bali.

Gejala ini perlu diatasi dengan mengarahkan para wisatawan ke daerahdaerah tujuan wisata potensi lainnya. Daerah-daerah tujuan wisata yang diperkirakan memiliki potensi pariwisata diharapkan dapat segera dikembangkan dan mampu menghasilkan keuntungan. Hal ini merupakan peluang emas yang segera bisa dimanfaatkan. Akan tetapi pemanfaatan peluang tanpa perencanaan yang matang bisa mendatangkan petaka. 
Sektor pariwisata merupakan salah satu sektor strategis dalam menggerakkan perekonomian Indonesia dan menjadi bagian dari perekonomian global. Berlangsungnya revolusi 3T, transport, telecomunication, tourism, menunjukkan bahwa kegiatan pariwasata telah menjadi salah satu kekuatan yang mampu mempercepat penyatuan dunia dalam integrasi ekonomi dan pergerakan manusia lintas daerah dan bahkan lintas negara (Rusman, 2004).

Konsentrasi pengembangan kepariwisataan Jawa Timur ditumpuhkan pada obyek wisata alam dan budaya. Perkembangan di masa mendatang diperkirakan akan mengikuti pola yang ada sekarang. Masih terpusatnya struktur kegiatan pariwisata di Jawa Timur mengakibatkan kurangnya kemampuan pelayanan fasilitas pariwisata yang ada dan menurunnya kualitas lingkungan wisata akibat penggunaan yang melebihi daya dukung.

Persoalannya sekarang adalah bagaimana membangun strategi agar masyarakat dapat menikmati hasil dari perkembangan tersebut. Tentu sangat ironis apabila terjadi sesuatu produk kebudayaan berkembang pesat, sementara kesejahteraan anggota masyarakat yang mendukungnya tidak pernah meningkat. Apapun bentuk perkembangan wisata budaya perlu diingat bahwa masyarakat bukan untuk pariwisata, tetapi sebaliknya harus berada pada landasan prinsip "pariwisata untuk masyarakat". Prinsip semacam ini lebih mendahulukan kepentingan masyarakat daripada kebutuhan masyarakat. Karena masyarakat sebagai subyek pariwisata, maka kebijaksanaan dan rencana pengembangan pariwisata harus terarah sedemikian rupa sehingga dalam diri setiap anggota masyarakat tumbuh rasa memiliki aset wisata yang ada disekitarnya.

Melihat posisi strategis wilayah Kabupaten Bojonegoro yang mempunyai luas wilayah 2.384,02 $\mathrm{km}^{2}$, dengan total populasi 1.213 .000 jiwa (2003) dan kepadatan 508,8 jiwa/km². Kabupaten Bojonegoro terdiri dari 27 kecamatan yang terbagi dalam 420 desa dan 11 Kelurahan. Kabupaten Bojonegoro berbatasan dengan Kabupaten Tuban di utara, Kabupaten Lamongan di timur, Kabupaten Nganjuk, Kabupaten Madiun, dan Kabupaten Ngawi di selatan, serta Kabupaten Blora (Jawa Tengah) di barat. Bagian barat Bojonegoro (perbatasan dengan Jawa 
Tengah) merupakan bagian dari Blok Cepu, salah satu sumber deposit minyak bumi terbesar di Indonesia.

Kabupaten Bojonegoro ditetapkan sebagai salah satu Daerah Tujuan Wisata (DTW) di Jawa Timur oleh Pemerintah, disamping itu Kabupaten Bojonegoro merupakan wilayah yang memiliki potensi obyek wisata alam dan budaya telah mendapatkan perhatian wisatawan nusantara pada umumnya dan keadaan ini ditunjang oleh beberapa faktor antara lain: a) keadaan topografis; b) keadaan geografis; c) keadaan sosial budaya; d) iklim, fauna dan kekayaan alam.

Dalam kebijaksanaan pengembangan yang tertuang dalam Rencana Induk Pengembangan Pariwisata (RIPP) Jawa Timur, Kabupaten Bojonegoro berada di kawasan C yang meliputi Kediri, Nganjuk, Pacitan, Ponorogo, Madiun, Magetan, Ngawi, Lamongan, dan Tuban. Pada kawasan ini wisata yang dikembangkan adalah wisata pantai dan laut, wisata budaya, wisata alam, terutama telaga.

\section{Konsep Pengembangan Pariwisata}

Pariwisata adalah serangkaian kegiatan perjalanan yang dilakukan oleh perorangan atau keluarga ataun kelompok dari tempat tinggal asalnya ke berbagai tempat lain dengan tujuan melakukan kunjungan wisata dan bukan untuk bekerja atau mencari penghasilan di tempat tujuan.

Dalam penelitian ini batasan lingkup permasalahan yang akan diteliti adalah kawasan pariwisata Kabupaten Bojonegoro yang meliputi, kawasan wisata Kahyangan Api, kawasan wisata Waduk Pacal, dan kawasan Wana Wisata Dander.

Adalah upaya merancang produk dan layanan kawasan pariwisata agar unik dan berbeda dari produk dan layanan kawasan pesaing (Hermawan,2005). Upaya merancang keunikan dan perbedaan ini bisa berdasarkan konten (apa yang ditawarkan), konteks (bagaimana cara menawarkannya) dan infrastruktur.

Kawasan pariwisata Bojonegoro yang akan ditawarkan dan berbeda dengan kawasan pariwisata lain antara lain adalah : (1) Kayangann Api; (2) Tirtawana; (3) Waduk Pacal; (4) Bendung Gerak; (5) Tambang Minyak Tradisional; (6) Petilasan Anglingdharmo. 
Beberapa istilah dan pengertian/definisi pariwisata menurut Undang-undang nomor 9 tahun 1990 tentang kepariwisataan Yo Peraturan Pemerintah nomor 67 tahun 1996, sebagai berikut:

1. Wisata adalah kegiatan perjalanan atau sebagian dari perjalanan tersebut yang dilakukan secara sukarela serta bersifat sementara untuk menikmati obyek dan daya tarik wisata.

2. Pariwisata adalah segala sesuatu yang berhubungan dengan wisata, termasuk pengusahaan obyek dan daya tarik wisata serta usaha-usaha yang terkait dibidang tersebut.

3. Kepariwisataan adalah segala sesuatu yang berhubungan dengan penyelenggaraan pariwisata.

4. Wisatawan adalah orang yang melakukan kegiatan wisata

5. Usaha Pariwisata adalah kegiatan yang bertujuan menyelenggarakan jasa pariwisata, menyediakan atau mengusahakan obyek dan daya tarik wisata, usaha sarana pariwisata dan usaha lain yang terkait dibidang tersebut.

6. Obyek dan Daya Tarik Wisata (ODTW) adalah segala sesuatu yang menjadikan daya tarik bagi wisatawan untuk berkunjung baik yang bersumber dari alam, budaya maupun minat khusus.

7. Usaha Jasa Pariwisata adalah bentuk usaha masyarakat yang memberikan jasa pelayanan bagi wisatawan dan masyarakat yang meliputi jenis usaha jasa biro dan agen perjalanan wisata, pramuwisata, konvensi (perjalanan insentif), pameran , impresariat, konsultan pariwisata serta jasa informasi pariwisata.

8. Usaha Sarana Pariwisata adalah bentuk usaha masyarakat yang memberikan sarana pelayanan tempat, alat, benda, bahan dengan segala sesuatunya yang dibutuhkan dan dikonsumsi oleh wisatawan meliputi jenis usaha sarana akomodasi, makan, minum, angkutan wisata, sarana wisata tirta dan kawasan pariwisata.

Dalam Rencana Pembangunan Jangka Menengah Daerah (RPJMD) Kabupaten Bojonegoro Tahun 2013-2018, bahwa perkembangan pariwisata akan diarahkan pada pengembangan Pemasaran, pengembangan Destinasi, pengembangan Kemitraan, pengembangan Penataan Wilayah. 
Pengembangan pemasaran pariwisata ditujukan untuk menciptakan promosi pariwisata yang efektif dengan pendekatan profesional, kemitraan antara swasta, pemerintah, dan masyarakat serta memperkuat jaringan kelembagaan. Pengembangan Destinasi pariwisata ditujukan untuk meningkatkan pengelolaan destinasi wisata dan aset-aset warisan budaya menjadi obyek daya tarik wisata yang atraktif berbasis budaya dan mendorong investasi. Pengembangan kemitraan pariwisata ditujukan untuk mengembangkan dan memperkuat jaringan kerjasama antara pemerintah (pusat - kabupaten/kota), swasta dan masyarakat serta pelaku industri budaya dan pariwisata didalam maupun luar negeri dalam bidang penelitian, SDM, dan kelembagaan. Pengembangan penataan wilayah pariwisata ditujukan untuk pembangunan pariwisata yang dapat menimbulkan daya tarik bagi wisatawan mancanegara dan wisatawan nusantara.

World Tourism Organizatio, (1955a) menyepakati bahwa pariwisata telah menjadi fenomena sosial ekonomi yang sangat penting dalam perkembangan kehidupan dan pergaulan global antar bangsa-bangsa di dunia. Pariwisata menjadi esensial bagi kehidupan karena terkait langsung dengan dampaknya pada perkembangan ekonomi, sosial budaya, dan pendidikan baik dalam lingkup nasional maupun internasional. Dari sisi spasial kegiatan pariwisata bersinggungan langsung dengan ruang dan waktu karena hakekatnya adalah pergerakan manusia dari satu tempat ke tempat lain.

Menurut Cooper (1993), pariwisata adalah serangkaian kegiatan perjalanan yang dilakukan oleh perorangan atau keluarga ataun kelompok dari tempat tinggal asalnya ke berbagai tempat lain dengan tujuan melakukan kunjungan wisata dan bukan untuk bekerja atau mencari penghasilan di tempat tujuan. Kunjungan dimaksud bersifat sementara (1 hari, 1minggu, 1 bulan) dan pada waktunya akan kembali ke tempat tinggal semula. Jadi ada dua elemen penting yaitu : perjalanannya itu sendiri dan tinggal sementara di tempat tujuan dengan berbagai aktivitas wisatanya.

Undang-Undang RI Nomor 9 tahun 1990 menyebutkan bahwa wisata adalah kegiatan perjalanan yang dilakukan secara sukarela serta bersifat sementara untuk menikmati obyek dan daya tarik wisata (pasal 1 ayat 1). Jadi kegiatan pariwisata 
141 - Potensi dan Kendala Pengembangan Pariwisata Berbasis Kekayaan Alam, ........

adalah kegiatan bersenang-senang (leisure) yang mengeluarkan uang atau tindakan konsumtif.

Pada dasarnya wisatawan dibedakan antara wisatawan nusantara (wisnus) yaitu penduduk Inndonesia yang melakukan perjalanan wisata di dalam negeri, disebut juga domestic tourist, wisatawan nasional (wisnas) adalah penduduk Indonesia yang melakukan perjalanan ke luar negeri, disebut juga outbound tourist, serta wisatawan mancanegara (wisman), yaitu penduduk luar negeri yang berkunjung ke Indonesia, disebut juga inbound tourist.

Wisatawan Nusantara (domestic tourist) adalah penduduk Indonesia yang melakukan perjalanan dalam wilayah geografis Indonesia (perjalanan dalam negeri) secara sukarela kurang dari satu tahun dan bukan untuk tujuan bersekolah atau bekerja, serta sifat perjalanannya bukan rutin (commuting), dengan kriteria :

1. Mereka yang melakukan perjalanan ke obyek wisata komersial, tidak memandang apakah menginap di hotel/penginapan ataupun tidak serta tidak melihat jarak perjalanannya.

2. Mereka yang melakukan perjalanan bukan ke obyek wisata komersial tetapi menginap di hotel/penginapan komersial, walaupun jarak perjalanannya kurang dari $100 \mathrm{~km}$ pp.

3. Mereka yang melakukan perjalanan bukan ke obyek wisata komersial dan tidak menginap di hotel/penginapan komersial tetapi jarak perjalanannya lebih dari 100 $\mathrm{km}$ pp.

Pentingnya konsep domestic tourist ini diperkuat oleh Cooper (1993) yang menyatakan : (1) jumlah wisatawan domestik di negara manapun akan jauh lebih besar dibanding wisatawan asing yang berkunjung ke negara tersebut, (2) besarnya jumlah wisatawan domestik karena tidak saja mencakup perjalanan untuk bersenang-senang/leisure tetapi juga memasukkan perjalanan untuk tujuan bisnis, ibadah, kesehatan.

Sesuai dengan rekomendasi World Tourism Organizatio (1995a) dan International Union Office Travel Organization (IUOTO), batasan/definisi wisatawan mancanegara adalah setiap orang yang mengunjungi suatu negara di luar 
tempat tinggalnya, didorong oleh satu atau beberapa keperluan tetapi bukan untuk bekerja atau memperoleh penghasilan di tempat yang dikunjungi.

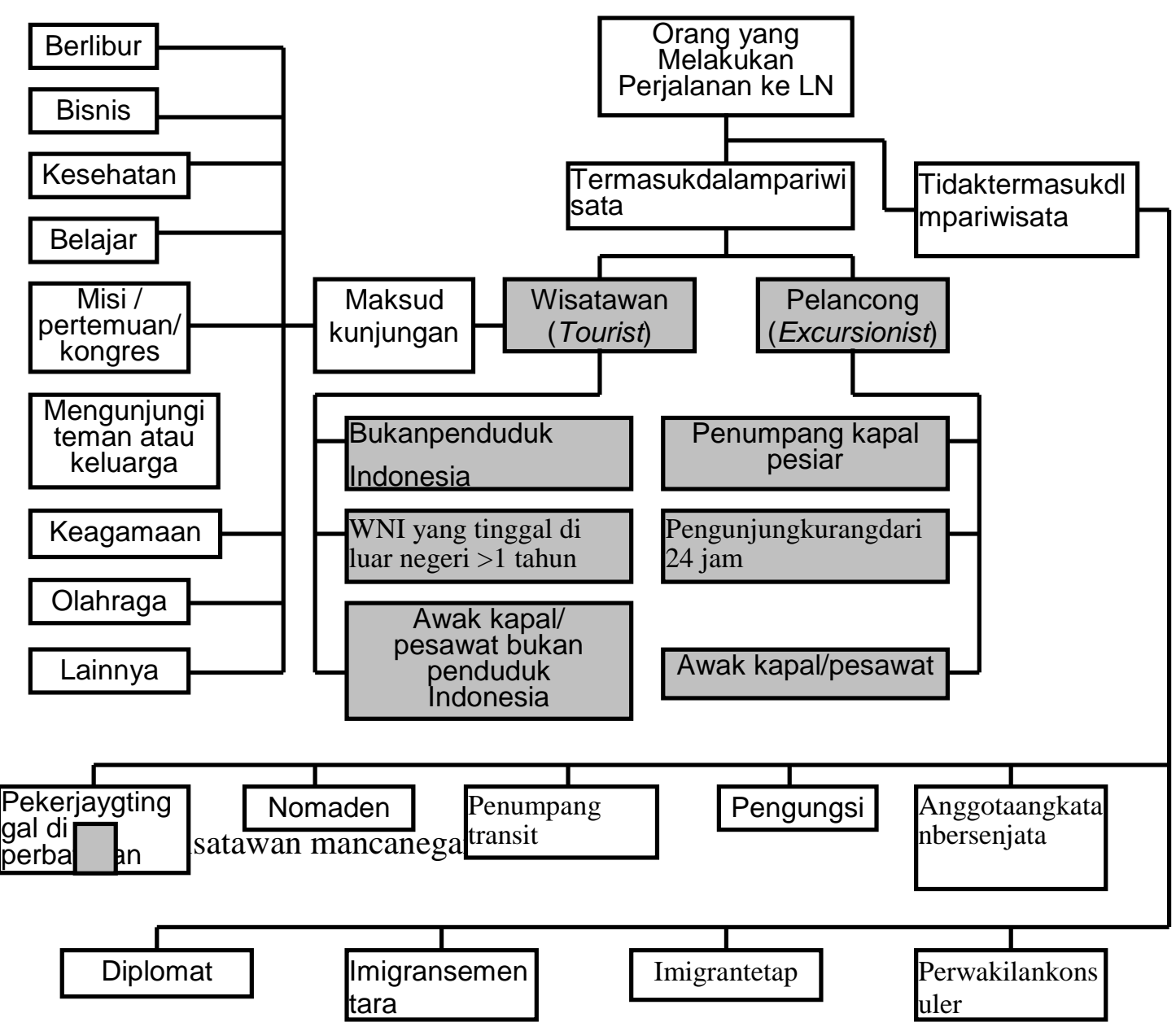

Sumber : Heriawan (2004)

Pada dasarnya wisman dibagi dalam dua golongan, yaitu :

1. Wisatawan (Tourist), yaitu pengunjung yang tinggal di negara yang dituju paling sedikit 24 jam, akan tetapi tidak lebih dari satu tahun, dengan tujuan : (1) berlibur, rekreasi, dan olah raga, (2) bisnis, mengunjungi teman dan keluarga, (3) misi, menghadiri pertemuan, konferensi, dan (4) kunjungan dengan alasan kesehatan, belajar, dan keagamaan.

2. Pelancong (Excursionist), yaitu pengunjung yang tinggal di negara yang dituju lebih atau kurang dari 24 jam, termasuk cruise passanger yang berkunjung ke 
suatu negara dengan kapal pesiar untuk tujuan wisata, dan biasanya tetap menginap di kapal bersangkutan.

Wisatawan nasional (wisnas) adalah penduduk Indonesia yang melakukan perjalanan ke luar negeri bukan untuk bekerja atau memperoleh penghasilan di luar negeri dan tinggal tidak lebih dari satu tahun dengan maksud kunjungan antara lain berlibur, pekerjaan/bisnis, kesehatan, pendidikan, misi/pertemuan/kongres, mengunjungi teman/keluarga, keagamaan, olahraga, dan lainnya. Pada dasarnya konsep outbound tourist sama dengan inbound tourist dalam hubungan yang terbalik

Menurut Rusman (2004), empat komponen utama menurut model Schmoll yang diyakini mempengaruhi keputusan wisatawan adalah :

1. Faktor Pendorong, yaitu kekuatan yang mendorong seseorang untuk bepergian (willingness to travel) : advertensi dan promosi, buku/booklet wisata, saran dan cerita dari wisatawan terdahulu, dan rekomendasi agen perjalanan.

2. Faktor Individu dan Sosial, yaitu kondisi dan sifat-sifat yang melekat pada wisatawan itu sendiri : status sosial dan ekonomi, perilaku personal, pengaruh sosial, sikap, dan nilai lingkungan.

3. Variabel Eksternal, yaitu gambaran tentang kondisi dan situasi perjalanan dan tempat tujuan wisata : keyakinan tentang keselamatan dan kemampuan operator wisata, citra mengenai daerah tujuan wisata dan pelayanannya, pengalaman perjalanan sebelumnya, keterjangkauan pada objek wisata, serta keterbatasan biaya dan waktu yang dimiliki.

4. Karakteristik Pelayanan di Tempat Tujuan, yaitu kondisi, situasi, dan citra dari negara/daerah tujuan dan objek wisata : hubungan biaya dan manfaat yang diperoleh, atraksi dan objek yang ditawarkan, jangkauan perjalanan, kualitas dan kuantitas informasi perjalanan, dan paket-paket perjalanan yang ditawarkan.

\section{Potensi Pariwisata Bojonegoro}

Pengembangan kawasan pariwisata di Kabupaten Bojonegoro menurut Dinas Kebudayaan dan Pariwisata termasuk kategori pengembangan destinasi pariwisata, dimana pola pengembangannya dapat dikelompokkan diantaranya, (1) kawasan wisata alam yang terdiri dari; Tanjung Kadok dan Gua Istana Maharani 
yang sekarang dijadikan satu paket dengan kawasan Wisata Bahari Bojonegoro (WBL), dan Waduk Gondang. (2) Kawasan Wisata Budaya yang terdiri dari;

Makam Sunan Drajat, Makam Sendang Dhuwur, dan Makam Nyai Putri Andongsari. (3) Kawsan Wisata Minat Khusus yang meliputi; TPI brondong, Monumen Kapal Van der Wijk, Sumber Air Panas Tepanas dan Pucak Wangi.

Menurut Hermawan (2005), saat ini daerah harus mulai menggeser pendeka tannya dalam hal pengelolaan dan pengembangan ekonomi daerah, dari pendekatan yang birokratis ke pendekatan strategic entrepreneurial.

Pendekatan birokratis adalah sebuah pendekatan pengelolaan daerah yang picik, karena selalu berorientasi pada prosedur dan aturan baku birokrasi yang menyebabkan daerah kehilangan kepekaan terhadap kebutuhan konstituennya.

Pendekatan strategic entrepreneurial bersifat pragmatis karena selalu berorientasi hasil dan peka terhadap setiap peluang, selalu fokus pada kebutuhan dan ekspektasi konstituennya dan yang tidak kalah pentingnya responsif terhadap setiap perubahan yang terjadi dalam lingkungan makro. Dengan pendekatan ini menuntut tiga elemen penting dalam perencanaan daerah yaitu, visi dan tujuan jangka panjang daerah, upaya membangun entrepreneurial ke segenap SDM daerah dan perumusan strategi daerah yang solid. Dengan tiga hal tesebut, alokasi sumber daya daerah akan efektif dan terarah sehingga keunggulan daerah dapat dibangun.

Dalam skala yang lebih luas (global-cosmopolit orientation) pemerintah daerah harus berupaya keras membangun kemampuan, inovasi, kapabilitas operasional, dan jaringan berskala global sebagai jembatan bagi mereka untuk dapat berpartisipasi dan mengambil keuntungan maksimal dari terbentuknya ekonomi global.

Dalam pengembangan pariwisata Bojonegoro perlu dilakukan beberapa analisis pentingsebagai berikut:

a. Analisis Perubahan Teknologi; dalam meninjau perubahan teknologi, pemasar kawasan pariwisata harus mengkaji berbagai aspek perubahan teknologi. Pertama, ia harus meninjau kemajuan dan kepesatan perkembangan teknologi dari waktu ke waktu, misalnya, perkembangan kemajuan teknologi telekomunikasi, seperti telpon seluler dan internet. Kedua, harus mampu 
mengidentifikasi berbagai kemungkinan dan potensi pemanfataan teknologi tersebut bagi kawasan pariwisata. Ketiga, harus melihat berbagai peluang yang muncul dari adanya pemanfataan teknologi tersebut, misalnya, semakin mudah dan murahnya sarana transportasi terutama udara, penggunaan teknologi dan mekanisme diberbagai bidang usaha.

b. Analisis Perubahan Politik dan Regulasi, dalam meninjau perubahan teknologi, pemasar kawasan pariwisata harus mengkaji berbagai perubahan politik. Pertama, pemasar kawasan pariwisata, harus meninjau karakteristik dan perilaku dari sistem politik yang berlaku. Kedua, pemasar kawasan pariwisata harus meninjau pengaturan institusi politik negara. Ketiga pemasar kawasan pariwisata harus mengkaji pengaruh perkembangan politik global,

\section{c. Analisis Perubahan Sosial Budaya}

Setiap daerah memiliki masyarakat yang hidup dengan prinsip dn keyakinan yang mereka pegang teguh sesuai dengan akar tradisi dan agama mereka. Nilainilai yang terkandung dalam tradisi dan agama tersebut akan tercermin dari setiap penganutnya dalam kehidupan sehari-hari sesuai dengan tingkat keyakinan dan interpretasi dari nilai-nilai yang diyakininya.

d. Analisis Perubahan Ekonomi, dalam melakukan analisis lingkungan ekonomi berbagai aspek perubahan ekonomi makro harus dikaji dan dicermati oleh pemasar kawasan pariwisata. Pertama, menyangkut sistem dan struktur ekonomi yang diadopsi oleh negara dan berbagai implikasi yang ditimbulkannya. Hal ini seiring dengan semakin menipisnya sumber daya yang ada terjadi perubahan paradigma perekonomian daerah dari eksploratif sumber daya alam, beralih pada orientasi menjadikan sumber daya alam tersebut sebagai komoditas akhir yang memiliki nilkai/harga paling tinggi. Kedua, menyangkut perkembangan kondisi ekonomi-politik makro. Perubahan orientasi sistem harga dari terkendali menjadi berdasarkan pada orientasi pasar. Perubahan ciri masyarakat pertanian dari berbasis pangan menjadi berorientasi pada pasar dan padat teknologi ramah 
lingkungan. Ketiga, menyangkut interaksi antara berbagai fenomena dan aktivitas ekonomi di dalam negara. Keempat, menyangkut sistem keuangan negara (financial system) dimana pemasar kawasan pariwisata harus meninjau interaksi dan berbagai perkembangan yang terjadi di dalam sistem keuangan negara. Hal ini ditandai dengan gencarnya persaingan antar wilayah untuk menarik investasi, baik dari dalam maupun luar negeri. Kelima, menyangkut dimensi regional dan internasional dari perekonomian negara dan daerah.

e. Analisis Perubahan Pasar, mengapa pemasar kawasan pariwisata harus melakukan tinjauan terhadap pasar ? Karena. Pertama, informasi tersebut bisa digunakan sebagai basis untuk penyusunan strategi pemasaran kawasan pariwisata, baik dalam penyusunan positioning, diferensiasi, strategi branding, pengembangan produk, strategi servis dan sebagainya. Kedua, dengan memahami karakteristik dan perkembangan pasar di suatu industri tertentu, pemasar kawasan pariwisata terutama dari kalangan pemerintah dapat merumuskan kebijakan yang dapat mendorong perkembangan industri tersebut.

Disamping itu, juga harus meninjau kondisi internal daerah baik berupa sumber daya maupun kompetensi yang dimiliki. Dari berbagai faktor internal daerah tersebut, harus dikelompokkan ke dalam faktor yang merupakan kekuatan dan faktor yang merupakan kelemahan kawasan pariwisata daerah. Tentu saja kekuatan dan kelemahan ini ditetapkan secara relatif terhadap pesaing.

Setelah ancaman dan peluang yang datang dari lingkungan eksternal dan kekuatan dan kelemahan yang datang dari faktor internal mampu dipetakan, selanjutnya akan didapatkan gambaran mengenai posisi kita. Berdasarkan posisi itulah kita akan dapat menyusun strategi umum yang akan dijalankan untuk memenangkan persaingan. Dan yang terakhir dalam membangun dan mengembangkan strategi Marketing Places kawasan pariwisata Bojonegoro adalah merumuskan Strategic Place Triangle (SPT). 


\section{Kendala Pengembangan Pariwisata}

Akan tetapi upaya pengembangan sektor pariwisata banyak mengalami kendala, sehingga sektor ini selama ini seolah tampak tidak ada pengembangan yang berarti. Menurut beberapa narasumber terpercaya seperti Sekretaris Dinas Pariwisata Bapak Sudaris Yuwono, Kepala Bagian Pengembangan Pariwisata Bapak M. Ahmad, dan seorang staf bagian kebudayaan Bapak Saeran bahwa hampir sebagian besar objek wisata kabupaten Bojonegoro berada di kawasan yang dikuasai oleh dinas kehutanan. Sementara itu koordinasi dengan dinas kehutanan selama ini tidak berjalan seperti yang diharapkan. Oleh karena situasi yang demikian maka pengembangan pariwisata selama ini agak sedikit terkendala.

Perkembangan terakhir, berdasarkan penjelasan Bapak Sudaris Yuwono, Bapak Bupati telah menjalin kerjasama untuk mengembangkan objek wisata khususnya Tirta Wana dijadikan wilayah wisata yang terintegrasi dengan Kolam renang dan Water Boom, Lapangan Golf, Khayangan Api, Agrowisata dan Hutan Lindung. Konsultan yang dilibatkan berasal dari Universitas Indonesia, serta investornya juga telah siap ada. Nantinya objek wisata Tirta Wana akan setaraf dan sekaligus terhubung sebagai paket destinasi wisata mendampingi WBL (Wisata Bahari Lamongan). Pemerintah Propinsi Jawa Timur memiliki program untuk menyatukan paket wisata tiga wilayah yakni Lamongan, Tuban dan Bojonegoro. Tahap pengembangan objek wisata Tirta Wana ini sementara belum dapat berjalan lancar, meskipun telah ada investor yang siap, hal ini karena masih dalam tahap negosiasi dan kerjasama dengan dinas kehutanan.

Infrastruktur pendukung pariwisata seperti sikap masyarakat lokal terhadap pendatang, kekayaan budaya lokal, dan tempat penginapan / hotel, semua sudah cukup tersedia. Hotel-hotel sudah cukup tersedia di kota Bojonegoro dari kelas melati sampai dengan hotel berbintang, yang selama ini untuk menampung para pekerja migas dari dalam dan luar negeri. Demikian juga dengan seni dan budaya masyarakat terus dilestarikan secara berkesinambungan. Event-event seni budaya baik yang bersifat nasional dan internasional sudah sering diikuti dalam rangka mengenalkan kekayaan khasanah budaya dan masyarakat Bojonegoro. Yang belum terjadi dan yang telah diupayakan terus untuk pengembangan pariwisata ke depan 
adalah sinergi di antar potensi-potensi unsur-unsur pendukung yang telah lengkap seperti di atas.

\section{Kesimpulan}

Potensi kabupaten Bojonegoro sangat besar untuk dapat berkembang menjadi kota yang maju dan sejahtera. Hal ini karena di dukung oleh kekayaan alam yang sangat besar, di samping juga kekayaan sosial budaya masyarakatnya. Kekayaan yang sangat menonjol dan sangat menyokong perkembangan kabupaten Bojonegoro antara lain: minyak dan gas bumi, air yang berlimpah (DAS Bengawan Solo, Air Umbulan Tirta Wana), dan kawasan hutan alam. Dari sisi kekayaan sosial budaya, menurut penjelasan seorang nara sumber Ninik staf bagian Kebudayaan, masyarakat Bojonegoro memiliki berbagai kekayaan seni dan budaya yang bahkan sering mewakili Jawa Timur untuk pentas seni dan budaya untuk tingkat nasional.

Di sisi lain, potensi tersbut di atas belum dapat dimaksimalkan dengan baik. Sebagai contoh, selama ini PAD (Pendapatan Asli Daerah) sebagian besar hanya di topang dari sektor migas. Sektor migas ini menyumbang APBD sangat besar, akan tetapi di sisi lain kesejahteraan masyarakat belum dapat sepenuhnya di capai. Sebagaimana diketahui kontrak-kontrak migas berlaku selama sekitar 25 tahun, meskipun cukup lama akan tetapi perlu diperhatikan sisi kesinambungannya, di samping sisi-sisi lain seperti lingkungan dan minimnya menyedot tenaga kerja karena merupakan penerapan teknologi tinggi. Peningkatan pendapatan daerah akan dapat memicu pembangunan di sektor lain, seperti pariwisata. Pemerintah kabupaten Bojonegoro memahami pentingnya mengembangkan sektor pariwisata karena sektor ini akan dapat memacu sektor-sektor yang lain terutama ekonomi dan kesejahteraan masyarakat. 


\section{Daftar Pustaka}

Alex S. Nitisewito, Marketing, ghalia Indonesia, Jakarta, 1991. 2.

Alkadri, dkk, Manajemen Teknologi Untuk Pengembangan Wilayah,- Konsep Dasar, Contoh Kasus,dan Implikasi Kebijakan-, Penerbit Pusat Kajian Kebijakan Teknologi Pengembangan Wilayah (P2KTPW) BPPT, Jakarta, 2001.

Basu Swasta DH dan Irawan, Manajemen Pemasaran Mpdern, Edisi kedua, Liberty, 1992

Basu Swastha DH, Azas-azas Marketing, Ghalia Indonesia, Jakarta, 1988

Dwijowijoto, Riant Nugroho, Kebijakan Publik- Formula,Implementasi, dan Evaluasi-, PT. Alex Media Komputindo, Jakarta, 2003

Hunger J. David \& Thomas L Wheelen, Manajemen Strategis, Penerbit ANDI, Yogyakarta, 2003

Kartajaya Hermawan, dan Yuswohadi, Attracting- Tourists, Traders, InvestorsStrategi Pemasaran Daerah di Era Otonomi, Gramedia Pustaka Utama, Jakarta, 2005.

Kountour, Ronny, Motede Penelitian,- Untuk Penulisan Skripsi dan Tesis,Penerbit PPM, Jakarta, 2004.

Peraturan Daerah Propinsi Jawa Timur Nomor 8 Tahun 2005, RPJMD Prop. Jawa Timur Tahun 2006 - 2008.

Peraturan Daerah Kabupaten Bojonegoro No. Tahun 2013 tentang, Rencana Pembangunan Jangka Menengah Daerah (RPJMD) Kabupaten Bojonegoro tahun $2013-2018$.

Phillp Kotler, Marketing Management, Prentice-Hall International, Inc., 2003.

Phillip Kotler, dkk, Rethinking Markerting - Sustainable Market-ing Entreprise di Asia, PT. Prenhallindo, Jakarta, 2003. Philip Kotler, dkk, Marketing Asian Places - Attracting Invesment, Industry, and Tourism to Cities, States and Nations, John Wiley \& Sons (Asia) Pte Ltd, 2002.

Stoner James A.F., dan R. Edward Freeman, Management, Intermedia, Jakarta, 1994. 